Journal of Applied Biology \& Biotechnology Vol. 5 (02), pp. 017-022, March-April, 2017

Available online at http://www.jabonline.in

DOI: 10.7324/JABB.2017.50203

(c) $\mathrm{EY}$-NC-SA

\title{
Medicinal and Functional Values of Thyme (Thymus vulgaris L.) Herb
}

\author{
Eqbal M. A. Dauqan ${ }^{1 *}$, Aminah Abdullah ${ }^{1,2}$ \\ ${ }^{1}$ School of Chemical Sciences and Food Technology Faculty of Science and Technology, Universiti Kebangsaan Malaysia, 43600 Bangi Selangor, \\ Malaysia. ${ }^{2}$ Universiti Islam Malaysia, Blok I, Bangunan MKN Embassy Techzone, Jalan Teknokrat 2, 63000 Cyberjaya, Selangor Darul Ehsan, Malaysia.
}

\section{ARTICLE INFO}

Article history:

Received on: 03/09/2016

Accepted on: 06/12/2016

Available online: 20/03/2017

Key words:

Thymus vulgaris L.,

thymol, carvacrol,

antioxidants, antimicrobial.

\begin{abstract}
Thymus vulgaris L. (T. vulgaris) a significant aromatic plant with around 100 species in the world is widely used for medicinal purposes as well as in culinary dishes. The genus Thymus are important medicinal plants, highly recommended due to a variety of therapeutic properties of their essential oils, normally known as Thyme oil. Thymus species are considered as medicinal plants due to their pharmacological and biological properties. Its properties are due to its main components, thymol and carvacrol. Fresh Thyme has the highest level of antioxidants among all herbs. Thymus vulgaris L. is widely used in folk medicine in the treatments of variety of diseases such as gastroenteric and bronchopulmonary disorders. The essential oil of thyme and the compound thymol have antimicrobial activity in vitro against E. coli strains. The essential oil of thyme has been found to possess the strongest antimicrobial properties. Thus the highlight of this paper was to review the medicinal and functional values of Thyme (Thymus vulgaris $L$.) herb.
\end{abstract}

\section{INTRODUCTION}

Nowadays, there are increasing consumer demands for foods which contain ingredients that may impart health benefits beyond basic nutrition, including herbal. They represent not only a suitable medium for the dissolution of functional components, but also a convenient method of consumption [1]. Thyme essential oil constitutes raw material in perfumery and cosmetics due to a special and characteristic aroma [2]. The potential source of natural antioxidants is plants, fruits and vegetables [3]. Thyme contains many flavonoids, phenolic antioxidants like zeaxanthin, lutein, pigenin, naringenin, luteolin and thymonin. Fresh Thyme herb has one of the highest antioxidant levels among herbs. It is packed with minerals and vitamins that are essential for optimum health. Its leaves are one of the richest sources of potassium, iron, calcium, manganese, magnesium and selenium [4]. Thymol are the main phenolic components that are primarily responsible for its antioxidative activity [5]. The herb Thymus vulgare Linn, Labiatae is pungent in taste and contains moisture, protein, fat, crude fibre, $\mathrm{Ca}, \mathrm{K}, \mathrm{Na}, \mathrm{Fe}, \mathrm{P}$, vitamin $\mathrm{A}, \mathrm{B}$ and vitamin $\mathrm{C}$. The main constituent of the oil extracted from Thyme is thymol $[4,6]$.

* Corresponding Author

Eqbal M. A. Dauqan, School of Chemical Sciences and Food Technology Faculty of Science and Technology, Universiti Kebangsaan Malaysia,

43600 Bangi Selangor, Malaysia.E-mail: edouqan@gmail.com
The herb is also a rich source of many important vitamins such as B-complex, folic acid, beta carotene, vitamin A, K, E and C. Thyme provides $0.35 \mathrm{mg}$ of vitamin B-6 or pyridoxine; furnishing about $27 \%$ of daily recommended intake. Pyridoxine keeps up gamma-aminobutyric acid (GABA) (beneficial neurotransmitter in the brain) levels in the brain, which has stress buster function [4].

Vitamin C helps body develop resistance against infectious agents and scavenge harmful, pro-inflammatory free radicals. Vitamin A is a fat soluble vitamin and antioxidant that is required maintaining healthy mucus membranes and skin and is also essential for vision. Consumption of natural foods rich in flavonoids like vitamin A and beta-carotene helps protect from lung and oral cavity cancers $[4,6]$.

Thyme is herbaceous plant of the platoon species, grows in mountainous areas, used as a beverage instead of or with tea, added to some food to give it an acceptable flavour, the plant is used in folk medicine frequently where it is prescribed to treat mouth infections, stomach, intestine and airways, coughing and gastroenteritis and expel intestinal worms, as well as to strengthen the heart [3]. Extracts from Thyme have been used in traditional medicine for the treatment of several respiratory diseases like asthma and bronchitis and for the treatment of other pathologies thanks to several properties such as antiseptic, antispasmodic, antitussive antimicrobial, antifungal, antioxidative, and antiviral [7]. 
The medicinal variety is known as common Thyme or garden Thyme, the same variety that is most often used for seasoning. Medicinal preparations of common Thyme are made from the leaves and the flowers [8]. Thyme essential oil also has medicinal applications. Thyme is combined with other herbs to treat ailments that range from bronchitis and sore throat to gastritis and skin disorders. Drinking Thyme tea on a regular basis even helps with arthritis. In the Middle ages Thyme was used as a food preservative and an incense [9]. Thus the aim of the present article was to review medicinal and functional values of Thyme (Thymus vulgaris $L$.) herb.

\section{PLANT DESCRIPTION}

Thyme is a tiny perennial shrub, with a semi evergreen ground cover that seldom grows quite to $(40 \mathrm{~cm})$ with horizontal and upright habits [10]. Figure 1. Shows the Thymus vulgaris L. [11]. The stems become woody with age. Thyme leaves are very little, usually 2.5 to $5 \mathrm{~mm}$ long and vary significantly in form and hair covering, depending on the variety, with every species having a rather completely different scent. $T$. vulgaris leaves are oval to rectangular in form and some what fleshy aerial components are used for volatile oil production, principally by steam distillation. The contemporary and dried herb market uses it for cooking [12].

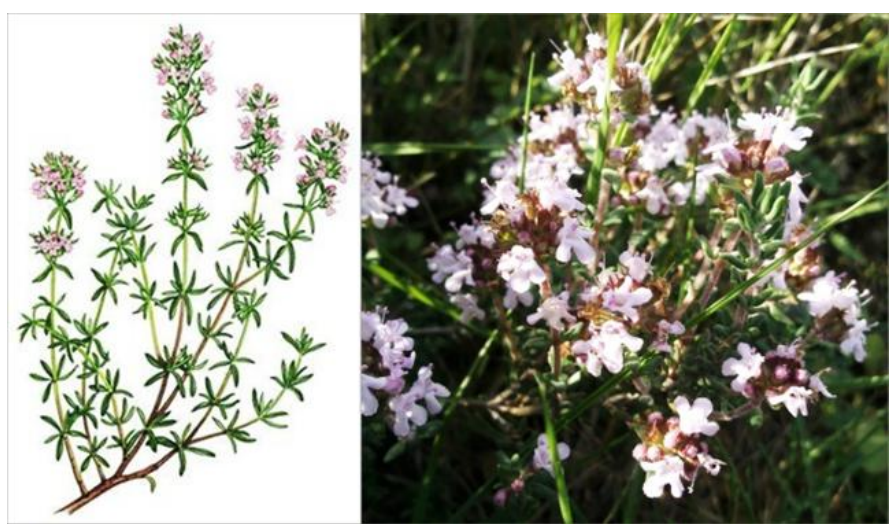

Fig. 1: Thymus vulgaris L [11].

Thyme grows well in a temperate to heat, dry, sunny climate, and wherever the plants don't seem to be shaded. The dried product should be processed to get rid of the leaves from the stems, and so sieved to get rid of dirt and to provide a consistent product [12]. Many strategies exist from sun to classy driers. The employment of sun-drying strategies leads to poor quality of the volatile oil. Artificial drying strategies permit higher management of product quality. Thyme should to be dried at temperatures not more than $40^{\circ} \mathrm{C}$ to cut back loss of flavor through volatilisation of volatile oil, and to keep up a decent inexperienced color [12] .

\subsection{Classification}

(Directorate Agricultural Information Services 2009).

$\begin{array}{ll}\text { Kingdom: } & \text { Plantae } \\ \text { Subkingdom: } & \text { Tracheobionta } \\ \text { Superdivision: } & \text { Spermatophyta } \\ \text { Division: } & \text { Magnoliophyta } \\ \text { Class: } & \text { Magnoliopsida } \\ \text { Subclass: } & \text { Asteridae } \\ \text { Order: } & \text { Lamiales } \\ \text { Family: } & \text { Lamiaceae } \\ \text { Genus: } & \text { Thymus L. } \\ \text { Species: } & \text { Thymus vulgaris L. }\end{array}$

\section{ORIGIN AND DISTRIBUTION}

Thyme is the general name for the many herb varieties of the Thymus species, all of which are native to Europe and Asia. Common or garden Thyme is considered the principal type, and is utilized commercially for flowering and ornamental purposes [13]. Thyme is native to the Western Mediterranean region, extending to south-eastern Italy.

The name Thyme, in its Greek form, was first given to the plant by the Greeks as a derivative of a word which meant 'to fumigate,' either because they used it as incense, for its balsamic odour, or because it was taken as a type of all sweet-smelling herbs. Others derive the name from the Greek words thyo, meaning perfume or Thymus, signifying courage, the plant being held in ancient and medieval days to be a great source of invigoration, its pleasant qualities inspiring courage. Another source quotes its use by the Sumerians as long ago as 3, $500 \mathrm{BC}$ and to the ancient Egyptians who called it tham [14].

\section{CHEMICAL COMPOSTOPN OF THYME ESSENTIOAL OIL}

Oils are very complex natural mixtures which can contain about $30-60$ components at quite different concentrations. Generally, these major components determine the biological properties of the essential oils [15]. Table 1 shows the chemical composition of the essential oil of T. Vulgaris.

Table 1: Chemical compostopn of thyme essentioal oil.

\begin{tabular}{ccc}
\hline Component & Formula & Relative concentration (\%) \\
\hline 3-Hxenol & $\mathrm{C}_{6} \mathrm{H}_{12} \mathrm{O}$ & 0.10 \\
$\alpha$-Tujene & $\mathrm{C}_{10} \mathrm{H}_{16}$ & 1.52 \\
$\alpha$-Pinene & $\mathrm{C}_{10} \mathrm{H}_{16}$ & 1.31 \\
Camphene & $\mathrm{C}_{10} \mathrm{H}_{16}$ & 0.75 \\
Sabinene & $\mathrm{C}_{10} \mathrm{H}_{16}$ & 0.84 \\
3-Otenol & $\mathrm{C}_{8} \mathrm{H}_{16} \mathrm{O}$ & 0.36 \\
3-Otanone & $\mathrm{C}_{8} \mathrm{H}_{16} \mathrm{O}$ & 0.20 \\
$\beta$-Myrcene & $\mathrm{C}_{10} \mathrm{H}_{1}$ & 60.67 \\
3-Otanol & $\mathrm{C}_{8} \mathrm{H}_{18} \mathrm{O}$ & 0.21 \\
$\alpha$-Pellandrene & $\mathrm{C}_{10} \mathrm{H}_{16}$ & 0.10 \\
$\delta$-3-Carene & $\mathrm{C}_{10} \mathrm{H}_{16}$ & 0.11 \\
$\alpha$-Terpinene & $\mathrm{C}_{10} \mathrm{H}_{16}$ & 2.36 \\
$\rho$-Cymene & $\mathrm{C}_{10} \mathrm{H}_{14}$ & 7.61 \\
Sylvestrene & $\mathrm{C}_{10} \mathrm{H}_{16}$ & 0.34 \\
1,8-Cineol & $\mathrm{C}_{10} \mathrm{H}_{18} \mathrm{O}$ & 0.57 \\
cis-Oimene & $\mathrm{C}_{10} \mathrm{H}_{16}$ & 0.22 \\
$\beta$-Oimene & $\mathrm{C}_{10} \mathrm{H}_{16}$ & 0.20 \\
$\gamma$-Terpinene & $\mathrm{C}_{10} \mathrm{H}_{16}$ & 9.50 \\
cis-Sabinene & $\mathrm{C}_{10} \mathrm{H}_{8} \mathrm{O}$ & 0.10 \\
\hline
\end{tabular}




\begin{tabular}{ccc}
\hline 3-Nonenol & $\mathrm{C}_{9} \mathrm{H}_{20} \mathrm{O}$ & 0.12 \\
3-Nonene & $\mathrm{C}_{9} \mathrm{H}_{18}$ & 0.22 \\
$\alpha$-Terpinolene & $\mathrm{C}_{10} \mathrm{H}_{16}$ & 3.27 \\
Linalool & $\mathrm{C}_{10} \mathrm{H}_{18} \mathrm{O}$ & 0.93 \\
Terpineol & $\mathrm{C}_{10} \mathrm{H}_{18} \mathrm{O}$ & 1.37 \\
Carene & $\mathrm{C}_{10} \mathrm{H}_{16}$ & 0.35 \\
E-Citral & $\mathrm{C}_{10} \mathrm{H}_{16} \mathrm{O}$ & 0.54 \\
3,4-Octadienal & $\mathrm{C}_{8} \mathrm{H}_{14} \mathrm{O}$ & 0.23 \\
Verbenol & $\mathrm{C}_{10} \mathrm{H}_{16} \mathrm{O}$ & 0.12 \\
endo-Borneol & $\mathrm{C}_{10} \mathrm{H}_{18} \mathrm{O}$ & 0.10 \\
4-Terpineol & $\mathrm{C}_{10} \mathrm{H}_{18} \mathrm{O}$ & 1.44 \\
$\alpha$-Terpineol & $\mathrm{C}_{10} \mathrm{H}_{18} \mathrm{O}$ & 1.63 \\
Dihydrocarvone & $\mathrm{C}_{10} \mathrm{H}_{16} \mathrm{O}$ & 0.10 \\
Decanal & $\mathrm{C}_{10} \mathrm{H}_{20} \mathrm{O}$ & 0.12 \\
9- $\rho$-Menthenol & $\mathrm{C}_{10} \mathrm{H}_{16} \mathrm{O}$ & 0.23 \\
2,6-Octadienal & $\mathrm{C}_{8} \mathrm{H}_{12} \mathrm{O}$ & 0.14 \\
Anisole & $\mathrm{C}_{7} \mathrm{H}_{18} \mathrm{O}$ & 0.23 \\
Geraniol & $\mathrm{C}_{10} \mathrm{H}_{18} \mathrm{O}$ & 0.10 \\
Citral & $\mathrm{C}_{10} \mathrm{H}_{16} \mathrm{O}$ & 0.24 \\
Thymol & $\mathrm{C}_{10} \mathrm{H}_{14} \mathrm{O}$ & 54.26 \\
Carvacrol & $\mathrm{C}_{10} \mathrm{H}_{14} \mathrm{O}$ & 4.42 \\
Octadienoic acid & $\mathrm{C}_{18} \mathrm{H}_{12} \mathrm{O}$ & 0.10 \\
Geranic acid & $\mathrm{C}_{10} \mathrm{H}_{16} \mathrm{O} 2$ & 0.30 \\
\hline Se [15] & &
\end{tabular}

Source: [15]

Essential oil: there are at least 6 chemotypes of Thymus vulgaris with different compositions of the essential oil; only the 'thymol'-type with thymol as predominant compound complies with the definition in the European Pharmacopoeia. The dried herbal substance contains up to $2.5 \%$ essential oil; the main components are thymol, carvacrol, p-cymene, $\gamma$-terpinene, linalool, $\beta$-myrcene, terpinen-4-ol. Some compounds occur partly as glycosides [16]. The chemical structure of more important compounds. Thymol, carvacrol and p-cymene are presented in Figure 2 [17].
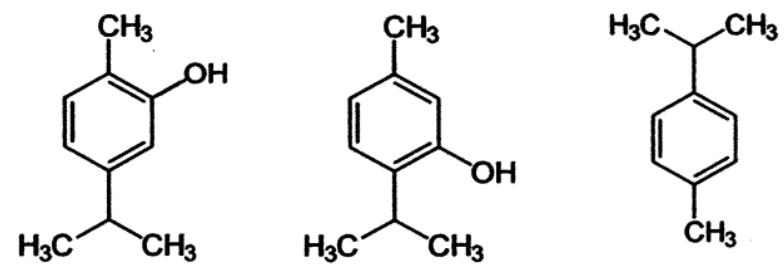

Fig. 2: The chemical structure of Thymol, carvacrol and p-cymen

Prasanth et al. (2014) reported that the essential oil from T. vulgaris showed a high content of oxygenated monoterpenes $(56.53 \%)$ and low contents of monoterpene hydrocarbons (28.69\%), sesquiterpene hydrocarbons $(5.04 \%)$ and oxygenated sesquiterpenes $(1.84 \%)$. The predominant compound among the essential oil components was thymol $(51.34 \%)$ while the amount of all other components of the oil was less than 19\% [12]. Table 2 shows the list of selected chemical constituents in Thymus vulgaris [18].

Table 2. List of selected chemical constituents in Thymus vulgaris

\begin{tabular}{llr}
\hline Chemical constituent & \multicolumn{1}{c}{ Biological activities } \\
\hline Thymol & $\begin{array}{l}\text { Antiseptic, antibacterial, antifungal and } \\
\text { antioxidant properties. }\end{array}$ \\
\hline Carvacrol & $\begin{array}{l}\text { Antimicrobial, antithrombotic, anti- } \\
\text { inflammatory, acetyl cholinesterase inhibitory } \\
\text { properties. }\end{array}$ \\
\hline Linalool & Antiviral effect, anti-inflammatory, antioxidant, \\
\hline
\end{tabular}

\begin{tabular}{ll}
\hline & anti-nociceptive as well as analgesic activity. \\
\hline Apigenin & $\begin{array}{l}\text { Anti-carcinogenic, anti-inflammatory, anti- } \\
\text { progression, anti-inflammatory, anti-viral and } \\
\text { anti-oxidant properties }\end{array}$ \\
\hline Eugenol & $\begin{array}{l}\text { Neuro-protective, anticancer, anti-bacterial and } \\
\text { anti-anaphylactic activities }\end{array}$ \\
\hline Rosmarinic acid & $\begin{array}{l}\text { Astringent, anti-allergic, anti-mutagen, anti- } \\
\text { oxidative and anti-inflammatory. }\end{array}$ \\
\hline Source: [18]. &
\end{tabular}

\section{THYME NUTRITIONAL VALUE}

The amazing Thyme benefits can be attributed to its rich nutritional value. The nutrients in Thyme have disease-preventing and health-promoting properties [19]. This aromatic herb is loaded with phytonutrients, minerals and vitamins which are vital for good health [19]. The in-depth nutritional profile of this herb is explained in the Table 3.

Table 3. The in-depth nutritional profile of T. Vulgaris

\begin{tabular}{|c|c|c|}
\hline \multicolumn{3}{|c|}{$\begin{array}{l}\text { Thyme herb (Thymus vulgaris), Fresh leaves, Nutritive value per } 100 \mathrm{~g} \\
\text { ORAC value 27426, (Source: USDA National Nutrient data base) }\end{array}$} \\
\hline $\begin{array}{c}\text { Principle } \\
\end{array}$ & Nutrient Value & Percentage of RDA \\
\hline Niacin & $1.824 \mathrm{mg}$ & $11 \%$ \\
\hline Pantothenic acid & $0.409 \mathrm{mg}$ & $8 \%$ \\
\hline Pyridoxine & $0.348 \mathrm{mg}$ & $27 \%$ \\
\hline Riboflavin & $0.471 \mathrm{mg}$ & $36 \%$ \\
\hline Thiamin & $0.48 \mathrm{mg}$ & $4 \%$ \\
\hline Vitamin-A & $4751 \mathrm{IU}$ & $158 \%$ \\
\hline Vitamin-C & $160.1 \mathrm{mg}$ & $266 \%$ \\
\hline Electrolytes & - & - \\
\hline Sodium & $9 \mathrm{mg}$ & $0.5 \%$ \\
\hline Potassium & $609 \mathrm{mg}$ & $13 \%$ \\
\hline Minerals & - & - \\
\hline Calcium & $405 \mathrm{mg}$ & $40.5 \%$ \\
\hline Iron & $17.45 \mathrm{mg}$ & $218 \%$ \\
\hline Magnesium & $160 \mathrm{mg}$ & $40 \%$ \\
\hline Manganese & $1.719 \mathrm{mg}$ & $75 \%$ \\
\hline Manganese & $106 \mathrm{mg}$ & $15 \%$ \\
\hline Zinc & $1.81 \mathrm{mg}$ & $16.5 \%$ \\
\hline Phyto-nutrients & - & \\
\hline Carotene- $\beta$ & $2851 \mu \mathrm{g}$ & - \\
\hline
\end{tabular}
Source: [19]

\subsection{Vitamins}

Thyme is also a good source of vitamins. It is particularly rich in Vitamin A and Vitamin C. Vitamin A is an antioxidant, vital for maintaining healthy mucus membranes and skin as well as good vision [19]. Vitamin C provides resistance against infectious diseases and fights harmful pro-inflammatory free radicals. Among the B-complex vitamins, it is a good source of Vitamin B6 or pyridoxine with a 100 gram serving providing about $0.35 \mathrm{mg}$ or $27 \%$ of the daily recommended intake of this vitamin [20]. This vitamin assists in maintaining GABA levels in the brain and acts as a stress buster. Other vitamins found in this herb include Vitamin K, Vitamin E and folic acid [19].

\subsection{Minerals}

Thyme is packed with minerals that are vital for optimum health. Its leaves are excellent sources of potassium, calcium, iron, manganese, magnesium and selenium. Potassium, being an important component of cells and body fluids, controls 
heart rate and blood pressure. Manganese is a co-factor for the antioxidant enzyme superoxide dismutase. Iron is involved in red blood cell formation $[4,19]$.

\subsection{Volatile Oils}

Thymol is one of the most important essential oils found in Thyme and known for its antiseptic and antifungal properties. It also contains other volatile oils such as carvacolo, geraneol and borneol [19, 21].

\subsection{Antioxidants}

Thyme is a rich source of flavonoid phenolic antioxidants such as zea-xanthin, pigenin, lutein, luteolin and thymonin [22]. Fresh Thyme boasts of a total ORAC (Oxygen Radical Absorbance Capacity) of 27426- $\mu$ mol TE/100 grams [19].

\section{ANTIOXIDANT PROPERTIES}

An antioxidant is a molecule that inhibits the oxidation of different molecules. Oxidation is a chemical process that transfers electrons or hydrogen from a substance to an oxidizing agent. Oxidation reactions will produce free radicals [23, 24]. In turn, these radicals will begin chain reactions. Once the chain reaction happens in a cell, it will cause damage or death to the cell. Antioxidants stop these chain reactions by removing free radical intermediates, and inhibit different oxidation reactions [24, 25]. The leafy parts of Thyme and its oil are utilized in foods for the flavor, aroma and preservation and additionally in folk medicines [10, 12]. El-Nekeety et al. (2011) conducted an experiment to work out the elements of Thymus vulgaris $L$. oil and to evaluate the protecting effects of this oil against aflatoxininduce oxidative stress in rats. The results indicated that the oil contains $\mathrm{c}$ arvarcrol (45 mg/g), Thymol $(24.7 \mathrm{mg} / \mathrm{g}), \beta$-Phellandrene $(9.7 \mathrm{mg} / \mathrm{g})$, essential oil ( $4.1 \mathrm{mg} / \mathrm{g})$, Humuline $(3.1 \mathrm{mg} / \mathrm{g}), \alpha$-Phellandrene $(2.3$ $\mathrm{mg} / \mathrm{g}$ ) and Myrcene $(2.1 \mathrm{mg} / \mathrm{g}$ ) [26]. However, $\alpha$ and $\beta$-pinene, Myrcene, $\alpha$-thyjone, Tricyclene, 1,8 -cineole, and $\beta$-sabinene were found in very lower concentrations. Treatment with aflatoxins alone disturbs lipid profile in blood serum, decreases total antioxidant capability, increase creatinine, uric acid and nitric oxide in blood serum and lipid peroxidation in liver and excretory organ attended with a sever histological changes within the liver tissues [26]. The oil alone at the two tested doses didn't induce any important changes within the biochemical parameters or the histological image. The combined treatment showed important enhancements of tested parameters and histological footage within the liver tissues. Moreover, this improvement was more pronounced within the cluster that received the high dose of the oil [27].

\section{PHARMACEUTICAL IMPORTANCE OF THYME VULGARUS}

Thyme has long history of being used in traditional medicine for treatment of various diseases for instance to treat respiratory diseases (whooping cough, bronchitis and asthma), in the form of tea, ointment, tincture, syrup or by steam inhalation [18]. It is also used to prevent hardening of the arteries, treatment of toothache, urinary tract infection and dyspepsia $[18,28]$. It also expels fungus from stomach and intestine and it has the ability to increase appetite because of its important component thymol, which has the ability to kill bacteria and parasites. Different studies were carried out in the last decades to reveal reported pharmacological activities of Thymus vulgaris both of plant extracts and essential oil. In mice analgesic and antipyretic properties were reported for Thyme extracts. Thyme has changed from a traditional herb to a serious drug rational phytotherapy. It is an incredible source of iron, calcium, manganese, vitamin $\mathrm{K}$ and likewise upgrades blood flow and pushes an invigorating impact for the entire system $[18,29]$.

This herb invigorated activity on anxious framework made it as a cure for physical and mental weakness and additionally for diminishing insomnia. The remedial potential of Thymus vulgaris is due to the presence of flavonoids, thymol, carvacrol, eugenol and phenols. Its controls numerous valuable effects, such as, antispasmodic, bactericides, antiseptics, antioxidants, anthelmintic properties and has lately been recommended as substitute for cancer prevention agent [18, 30]. Among different Thymus species, $T$. vulgaris is cultivated in many countries by most people especially in rural areas who depend on herbal medicines to treat many diseases including inflammationrelated ailments such as rheumatism, muscle swelling, insect bites and pains $[10,31]$.

T. vulgaris is used more in pharmaceutical dosage forms because it contains more essential oil than other species with high amount of thymol which exhibits considerable antitussive and expectorant effects $[10,32]$. Considering the fact that Thymus vulgaris is more expensive, some herbal industries tend to use other species of Thymus with different components [10].

\section{MEDICINAL APPLICATION}

The main component of the essential oil of Thyme, thymol, is active against Salmonella and Staphylococcus bacteria. The antiseptic and tonic properties of Thyme make it a useful tonic for the immune system in chronic, especially fungal, infections as well as an effective remedy for chest infections such as bronchitis, whooping cough, and pleurisy [33]. Thyme and Thyme oil have been used as fumigants, antiseptics, disinfectants, and mouth washes. The pleasant-tasting infusion can be taken for minor throat and chest infections, and the fresh leaves may be chewed to relieve sore throats. Thyme is prescribed with other herbs for asthma, hayfever, and is often used to treat worms in children [14].

Thyme has been thought to be antiseptic, antimicrobial, astringent, anithelmintic, carminative,disinfectant, medicinal drug and tonic [12]. Thyme is incredibly useful in cases of assorted intestinal infections and infestations, like hookworms,ascarids, gram-positive and gram negative bacteria, fungi and yeasts such as Candida albicans. Its active constituent, thymol, is active against enterobacteria and coccid bacteria. Thyme may also improve liver 
function and act as an appetite stimulant. It will be used in treatment of cartilaginous tube, bronchial and urinary infections $[10,34]$.

Thyme is helpful in treatment of laryngitis and inflammation. The main component of the volatile oil of Thyme, thymol,is active against enterobacteria [10]. It is used for skin issues like oily skin, sciatica, acne, dermatitis and bug bites. A corrected product, 'white Thyme oil' is also used and it's milder on the skin. Applied to the skin, thyme relieves bites and stings and relieves neuralgia and rheumatic aches and pains [12,35].

\subsection{Anti Bacterial Activity of $T$. vulgaris $\mathrm{L}$}

Prasanth et al. (2014) and Saleh et al. (2015) reported that the essential oils obtained from Thymus vulgaris $L$. harvested at 4 biological process stages were evaluated for their biological activity and chemical components. The Thyme volatile oils were analysed for their inhibition effects against 9 strains of gramnegative bacteria and 6 strains of gram-positive bacteria $[10,12]$.

The bioimpedance methodology was chosen for finding out the antibacterial activity of the essential oils and also the parameter chosen for outlining and quantifying the antibacterial activity of the Thyme oils was the detection time [12]. The plate counting technique was used to study the inhibitory effect by direct exposure. All the Thyme essential oils examined had a significant bacteriostatic activity against the microorganisms tested. This activity was more pronounced against the grampositive bacteria [36] .

The oil from Thyme fully flower was the foremost effective at stopping the growth of the microorganism species examined [36]. The oils tested were conjointly shown to possess smart antibacterial activity by direct contact, that gave the impression to be a lot of marked against the gram-negative microorganism. Some species were capable of recovering a minimum of $50 \%$ of their metabolic function once contact with the inhibitor, whereas most of the strains were shown to have been inactivated almost completely $[10,12]$.

\subsection{Antimicrobial Activity of $T$. vulgaris $L$}

Boruga et al. (2014) reported that the antimicrobial activity of essential oils depends on their chemical constituents. Apparently, the antimicrobial activity of the essential oil analyzed is related to the presence of phenolic compounds (thymol) and terpene hydrocarbons ( $\gamma$-terpinene), respectively [37].

p-Cymene, the third major element according to percentage, does not show antibacterial efficacy when used alone, synergistic effects being however attributed to it in relation to thymol and $\gamma$-terpinene, respectively, which might represent another cause of the antimicrobial activity recorded. On the other hand, a number of studies have shown that essential oils exhibit stronger antimicrobial activity than that of their major constituents or their mixtures, respectively, which suggests synergistic effects of the minor components, but also the importance of all components in relation to the biological activity of Eos [38, 39, 40]. Figure. 3 Shows the antimicrobial activity of Thyme oil, at different amounts, expressed as a mean inhibition zone for each of the nine repeated measurements [37] .

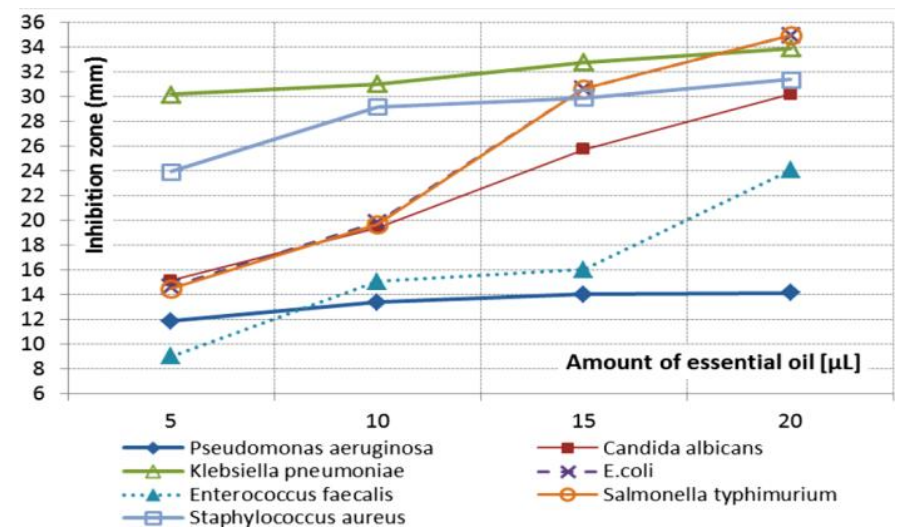

Fig. 3: The antimicrobial activity of Thyme oil, at different amounts, expressed as a mean inhibition zone for each of the nine repeated measurements [37].

\section{CONCLUSION}

Thyme (Thymus Vulgaris L.) is an important medicinal plant which belongs to the Lamiaceae family; it has been used for centuries as spice, home remedy, drug, perfume and insecticide. Thyme has antihyperglycemic and antilipidemic effect, and kidney functions improvement, which may be helpful in the treatment of diabetes and other diabetic related complications. Thymus Vulgaris essential oil is one of the most commonly used essential oils in the food industry and in cosmetics as preservatives and antioxidants .

\section{ACKNOWLEDGEMENT}

This work was supported by STGL-004-2007 (UKM), Universiti Islam Malaysia (UIM) and The Institute of International Education Scholar Rescue Fund (IIE-SRF), USA for research fellow.

Conflict of Interests: There are no conflicts of interest.

\section{REFERENCES}

1. Nanasombat S, Thonglong J, Jitlakha J. Formulation and characterization of novel functional beverages with antioxidant and anti-acetylcholinesterase activities. Functional Foods in Health and Disease. 2015; 5(1): 1-16.

2. Grigore A, Paraschiv INA, Colceru-mihul S, Bubueanu C, Draghici E, Ichim M. Chemical composition and antioxidant activity of Thymus vulgaris L. volatile oil obtained by two different methods. Romanian Biotechnological Letters, University of Bucharest. 2010; 15(4): 5436- 5443.

3. Mohamed A, Mohamed A, Omar AA. A study to find thyme oil dose that kill $50 \%$ of mice and minimal dose that kill all mice and maximum nonlethal Dose. Nature and Science. 2013; 11(12): 52-53.

4. Sharangi AB, Guha S. Wonders of leafy spices: Medicinal properties ensuring Human Health. Science International. 2013; 312-317, DOI: 10.17311/ sciintl.2013.312.317.

5. Alireza K, Faeghe H, Siamak S, Negar B. Study of the effect of extract of Thymus vulgaris on anxiety in male rats. Journal of Traditional and Complementary Medicine. 2015; 1-5. 
6. Aksel B. Bioactive compounds in plants - benefits and risks for man and animals. The Norwegian Academy of Science and Letters, Oslo. 13 - 14 November 2008.

7. Ocana A, Reglero G. Effects of Thyme extract oils (from Thymus vulgaris, Thymuszygis, and Thymus hyemalis) on cytokine production and gene expression of oxLDL-Stimulated THP-1Macrophages. Journal of Obesity. 2012; 1-11, Doi:10.1155/2012/104706.

8. Margaret E. Recognition for plant heritage thyme collection. Brickell Award for National Plant Collection Holder, Plant Heritage. 2011. http://www.thymus.co.uk/PlantHeritage-BrickellAward04072011.pdf

9. Hoopa Tribal Radio, KIDE. Health aatters, Thyme. The First Solar Powered Radio Station in California. 2014; 1-3.

10. Saleh H, Azizollah JK, Ahmadreza H, Raham A. The Application of Thymus vulgaris in traditional and modern medicine: A Review. Global Journal of Pharmacology. 2015; 9 (3): 260-266.

11. Echappees sauvages. Thym - Thymus vulgaris L. 2011. $\mathrm{http} / / / \mathrm{www}$.mauvaisesherbes.org/t1251-thym-thymus-vulgaris-1

12. Prasanth R, Ravi VK, Varsha PV, Satyam S. Review on Thymus vulgaris traditional uses and pharmacological properties. Med Aromat Plants. 2014; 3 (4):1-3.

13. Nadiya RM, Yadav KC, Anurag V. Optimization of process parameters in extraction of Thyme oil using response surface methodology (RSM). International Journal of Science, Engineering and Technology. 2016; 4(1): 248-256.

14. Directorate Agricultural Information Services. Department of Agriculture, Forestry and Fisheries Private Bag X144, Pretoria, 0001 South Africa. 2009.

http://www.daff.gov.za/docs/Brochures/EssOilsThyme.pdf

15. Fatimah AA. Chemical composition, antioxidant and antitumor activity of Thymus vulgaris L. essential oil. Middle-East Journal of Scientific Research. 2014; 21 (10): 1670-1676.

16. Committee on Herbal Medicinal Products. Assessment report on Thymus vulgaris L., vulgaris zygis L., herba. European Medicines Agency. 2013.

http://www.ema.europa.eu/docs/en_GB/document_library/Herbal__HMPC_assessment_report/2014/06/WC500167810.pdf

17. Taheri M, Maleknia L, Alizadeh GhN, Almasian A, Chizarif AGh. Effect of zirconium dioxide nanoparticlesas A mordant on properties of wool with Thyme: Dyeing, flammability and antibacterial. An International Open Free Access, Peer Reviewed Research Journal. 2014; 31(1):85-96.

18. Hina J, Shazia E, Sobia T, Farhana A. An overview on medicinal importance of thymus vulgaris. Journal of Asian Scientific Research. 2013; 3(10):974-982

19. Vineetha. 22 Amazing benefits and uses of Thyme. Health Beckon. 2014. http://www.healthbeckon.com/thyme-benefits/

20. National Institutes of Health. 2016. Vitamin B6. U.S. Department of Health \& Human Services. https://ods.od.nih.gov/factsheets/VitaminB6-HealthProfessional/

21. Moghtader M. Antifungal effects of the essential oil from Thymus vulgaris $L$. and comparison with synthetic thymol on Aspergillus niger. Journal of Yeast and Fungal Research. 2012; 3(6): $83-88$.

22. AgroWeb. Thyme - The timeless herb of albania. 2016. http://agroweb.org/article.html?id=10\&l=1229\&ln=en\&url=thymethe-timeless-herb-of-albania

23. Eqbal D, Aminah A, Halimah AS. Review Article: Natural antioxidants, lipid profile, and antioxidant enzyme of vegetable oils. Advance Journal of food science and technology. 2011; 3(4): 308 316.

24. Dipak P. Role of antioxidants in stability of edible oil. Journal homepage. 2013; 1(1): 68-73

25. Eqbal D, Halimah AS, Aminah A. Antioxidants enzyme: Effect of different concentrations of red palm olein and different vegetable oils on antioxidant enzymes on normal and stressed. INTECH. 2012; ISBN 980-953-307-108-9. Pages: 303-320.
26. El-Nekeety AA, Mohamed SR, Hathout AS, Hassan NS, Aly SE, Wahhab MA. Antioxidant properties of Thymus vulgaris oil against aflatoxin-induce oxidative stress in male rats. Toxicon. 2011; 57: 984-991.

27. Natalie B. 9 Health benefits of Thyme. Healthline - Food \& Nutrition. 2016. http://www.healthline.com/health/health-benefits-ofthyme\#1

28. Hashim S, Gamil M. Plants and herbs between the Iraqi folk medicine and scientific research. Baghdad, Dar revolution of Press and Publication. 1988.

29. Mohsin A, Shah AH, Al-Yahya MA, Tariq M, Tanira MOM, Ageel AM. Analgesic, antipyretic activity and phytochemical screening of some plants used in traditional arab system of medicine. Fitoterapia. 1989; 60(2): 174-177.

30. Monira A, Naima. Z. Evaluation of protective and antioxidant activity of thyme (Thymus vulgaris) extract on paracetamol-induced toxicity in rats. Australian Journal of Basic and Applied Sciences. 2012; 6(7): 467-474.

31. Namsa ND, Tag H, Mandal M, Kalita P, Das AK. An ethnobotanical study of traditional anti-inflammatory plants used by the Lohit community of Arunachal Pradesh. India J Ethnopharmacol. 2009; 125(2): 234-45.

32. Verpoorte R. Pharmacognosy in the new millennium: leadfinding and biotechnology. J. Pharm Pharmacol. 2000; 52: 253-262.

33. Marina S, Jasmina G, Petar DM, Dejan B, Leo JLD. Antibacterial effects of the essential oils of commonly consumed medicinal herbs using an in vitro model. Molecules. 2010; 15: 7532-7546. DOI: 10.3390/molecules 15117532 .

34. Hompson J, Chalcha J., Michet A, Linhart Y, Ehlers B. Qualitative and quantitative variation in monoterpene co-occurrence and composition in the essential oil of Thymus vulgaris chemotypes., J. Chem Ecol. 2003; 29(4): 859-80.

35. ESCOP Monographs: The scientific foundation for herbal medicinal products. The European Scientific Cooperative on Phytotherapy in collaboration with Georg Thieme. 2007.

36. Marino M, Bersani CC. Antimicrobial Activity of the Essential Oils of Thymus vulgaris L. Measured Using a Bioimpedometri Method. J Food Prot. 1999; 62: 1017-23.

37. Boruga O, Jianu C, Mişcă C, Goleț I, Gruia AT, Horhat FG. Thymus vulgaris essential oil: chemical composition and antimicrobial activity. Journal of Medicine and Life. 2014; 7( 3): 56-60

38. Gill AO, Delaquis P, Russo P, Holley RA. Evaluation of antilisterial action of cilantro oil on vacuum packed ham. International Journal of Food Microbiology. 2002; 73(1): 83-92.

39. Rota MC, Herrera A, Martínez RM, Sotomayor JA, Jordán MJ. Antimicrobial activity and chemical composition of Thymus vulgaris, Thymus zygis and Thymus hyemalis essential oils. Food Control. 2008; 19(7): 681-687.

40. Dorman HJD, Deans SG. Antimicrobial agents from plants: antibacterial activity of plant volatile oils. Journal of Applied Microbiology. 2000; 88(2): 308-316.

\section{How to cite this article:}

Dauqan EMA, Abdullah A. Medicinal and Functional Values of Thyme (Thymus vulgaris L.) Herb. J App Biol Biotech. 2017; 5 (02): 017-022. DOI: 10.7324/JABB.2017.50203 